Article

\title{
The Survival of the Gift: An Enchanted Interpretation of Early Quakerism
}

\author{
Benjamin J. Wood \\ Department of Theology \& Religious Studies, Leeds Trinity University, Brownberrie Ln, Horsforth, \\ Leeds LS18 5HD, UK; b.j.wood@hotmail.co.uk
}

Received: 12 October 2018; Accepted: 30 October 2018; Published: 16 November 2018

\begin{abstract}
Since Max Weber's ground-breaking study, The Protestant Ethic, and the Spirit of Capitalism, it has become something of a scholarly trope to treat the rise of secular modernity and the formation of Quakerism as going readily together. In an effort to dismantle this habitual interpretation of Quaker history, this article posits the existence of an embryonic 'enchanted' Quakerism, which actively resisted the nascent secularity of early modernity. Drawing extensively on the gift-theory of Marcel Mauss, it will be shown that first-generation Quakerism was characterised by a magical conception of the body, nature, and society. Such a posture, in its radical anachronism, sought to undermine both Cartesian science and the emerging discipline of political economy. In place of a cosmology of hierarchy and commodification, early Quakers argued for a sweeping theology of gift, which imbued the whole of experience with divine activity. While secularity was busily confining the magical and the miraculous to the realm of innermost subjectivity, the Quakerism of the 1650s and 60s was characterised by a stubborn refusal to accept such a process of religious privatisation. In contrast, early Quaker spirituality postulated the continual interaction of Biblical realities with contemporary natural and social orders.
\end{abstract}

Keywords: Quakerism; enchantment; Marcel Mauss; gift; secularity

\section{Introduction: Quakerism and Disenchantment}

Since Max Weber's ground-breaking study, The Protestant Ethic, and the Spirit of Capitalism, it has become something of a scholarly trope to treat the rise of secular modernity and the formation of Quakerism as going readily together. In this account, the first Quakers serve as unwitting agents in the transmission and reinforcement of the values of work, individualism, rationality, and asceticism, which would increasingly characterise the post-feudal societies of Europe. Gone were the Catholic sacramental system and the ecclesial cycle of feasts and fasts. In their place, the Protestant reformers instituted conditions of 'sobriety and hard work' (Weber 2002, p. 208). In the Quaker case, outward liturgies and sacraments were abandoned altogether (Penington 1995, p. 35). For Weber, such rejection was indicative of the implicit refusal of Protestant sectarians to acknowledge the existence of an enchanted cosmos. Catholic Christendom was enchanted, because God was not merely believed in, but regarded as 'inescapable' (Taylor 2007, p. 13). In this enchanted world, it was entirely rational to affirm the actions of spirits, the existence of witchcraft, or the living presence of the Eucharist, since subjectivity was not strictly confined to human agents (Taylor 2007, p. 35). As Charles Taylor summarises this state of affairs:

[In] the enchanted world, charged things have a causal power which matches their incorporated meaning ... Once meanings are not exclusively in the mind, once we can fall under the spell, enter the zone of exogenous meaning, then we think of this meaning as including us, or perhaps penetrating us. We are in as it were a kind of space defined by 
this influence. The meaning can no longer be placed simply within; but nor can it be located exclusively without' (Taylor 2007, p. 35).

In this way, the world was thought to gain its meaning through a plethora of divine and demonic agencies, which could be encountered by human beings through multiple objects, locations, or rites. In this mould, religion was not merely a cognitive exercise in 'belief', but a sensual activity, which relied on multiple forms of symbolic and ritual mediation. The expansive medieval cult of the saints is an excellent case in point, for it assumed a world where there was little division between the worlds of the dead or the living, the domain of the flesh, and the realm of the spirit. Yet, the Puritan sectarian (whether Calvinist, Pietist, or Quaker) was to avoid such sensual cosmologies assiduously, 'because they were no use for salvation and fostered sentimental illusions and superstitious idolatry' (Weber 2002, p. 74). However, as Taylor's remarks suggest, this rupture with the Catholic past was not merely aesthetic, but ontological. A central component of the Weberian thesis is that the Protestant sects accomplished an alteration in economic and social conditions by radically undercutting a sacred conception of the external world. Here, it is worth considering the ambiguous position of the Eucharist within the Reformation. While Luther had insisted that the believer's body was still a vessel for the transformed body of Christ as bread and wine (Mazza 1999, p. 238), Luther's own commitment to the radical interiority of faith stripped the Eucharistic rite of any hint of external power. Not only did Luther generally regard physical miracles as ceasing with the first Apostles (Rodman-Williams 1996, p. 159), he also saw the Eucharist as a reminder of Jesus's promises contained in the Words of Scripture, and not a supernatural sacrifice. Summarising the implications of these theological trajectories, Philip Mellor and Chris Shilling suggest:

Lived experience became devalued for Protestants, irrespective of how fearful or joyous it was, since 'the real' was a pale reflection of the 'ideal'. As the ... Quakers illustrate, religious life became an attempt to grasp something beyond earthly existence. God was no-longer imminent within a magical unpredictable world but was radically transcendent of His fallen creation (Mellor and Shilling 1997, p. 107).

In this vein, the founder of Quakerism, George Fox, is understood as a proto-modern figure, whose religiously-induced wandering is representative of a man who refused 'to attribute bodily relationships with sacred value' (Mellor and Shilling 1997, p. 101). Yet, is this really an accurate portrait of early Quakerism? The following article suggests that while Quaker communities after 1680 readily displayed many of the key features of Weber's 'Protestant ethic', first-generation Quaker leaders promoted a mode of religious life deeply at variance with the dynamics of developing secularity. At the centre of this analysis is the work of the early anthropologist, Marcel Mauss, and his 1925 study, The Gift. Here, Mauss contends that while modern societies are characterised by legal and market forms of exchange, 'archaic' pre-modern cultures were organised by codes of mutual and obligatory gift-exchange. In these societies, the 'gifts' circulated represented more than mere products to be utilised, but rather served as rich symbols of social life. Through a continual circulation of giving and receiving gifts, each member of the community felt themselves 'enmeshed with one another' (Mauss [1954] 2002, pp. 43-44). Thus, according to this ancient rationale, no transaction or acquisition could be regarded as separate from the needs of the community. There was no space for private transactions, nor for calculated accumulation. To refuse to give (or take too much) meant a magical repudiation of a tribal myth, an act of sacrilege, which would rebound on the refuser. At the heart of gift-economies was a sense of spiritual equilibrium, where the act of giving kept social and divine forces in balance. As Mauss observes: 'Gifts to humans and to the gods ... serve the purpose of buying peace between them both' (Mauss [1954] 2002, pp. 21-22). As I shall show, early Quaker preachers similarly viewed bodies, nature, and society, as produced and sustained by a continual chain of gift-relations between God and his creatures. In this way, early Quaker conceptions of 'the fall' were frequently expressed in terms of the repudiation of God's gifts, while redemption rested upon the believer's full participation in a sacred economy of gift-giving. 
In an effort to sketch the contours of this theological scheme, the first part of this article considers the relation between early Quaker religiosity, medicine, and the body. Through a close reading of early Quaker texts, it will be shown that, far from treating the body as devoid of spiritual significance, early Quakers affirmed a bio-spirituality, which linked physical healing to divine activity. Quaker preachers, through the gestures of their bodies, believed themselves capable of taking away diseases and physical distresses of all kinds. Unlike the priests and physicians whose services were cloaked in payment and privilege, the Quaker healing gift was open to all, dependent on both healers and patients making their lives gifts to God. What does such an account tell us about Quaker visions of nature? The second part of this article attempts to reconstruct early Quaker cosmology through an attentiveness to the theological categories of 'creation' and 'creature'. While Cartesian science was busily attempting to divide reality into the divine realm and the terrain of inert matter, Quakers held fast to the conception of a living world, which radiated divine grace and providence. Not only was their cosmology full of supernatural agencies, but one barely separated from the realm of eternity. What was it like to live in such a world? In the final part of this discussion, I relate these trajectories to the realities of 17 th century society. As eschatological agents living amid the perpetual coming of Christ and the unredeemed realities of rulers and magistrates, Friends found themselves existing in a kind of porous 'no-place', a community which existed outside all other earthly societies, and yet Friends found themselves strangely manifest in time. While Quakers lived their lives as sons, wives and husbands, householders, and traders, their eschatological identity restored to them the peaceful social order generated by the logic of grace. As we shall see, this new identity was intimately bound up with the radical way in which early Quakers interpreted Biblical texts. The horizon of Scripture not only rooted Friends in the ever-present reality of Christ, but also relativized all social loyalties, allowing Quakers to perceive the true commonwealth of gifts to which they belonged.

\section{Thomas Browne: An Enchanted Cosmos in Retreat}

Before examining the relation between the early Quaker movement and medicine, it will be necessary to properly orientate our inquiry by first considering the contested meanings of both healing and medicine in the context of the religious culture(s) of mid-17th century England. A key concern in the following discussion will be to ascertain the degree to which first-generation Quakers distinctively added to this complex discourse. By the 1650s, paradigms of healing and medicine were in a state of significant flux, oscillating between an older Paracelsian philosophy of nature and a secular-technical art. Meanwhile, the earlier medieval cosmology (with which medicine had been so intimately tied) existed in a state of considerable disintegration. Nowhere is this ambiguous situation better illustrated than in the life and work of the physician and antiquarian, Thomas Browne (1605-1682). As a physician trained in Italy and the Netherlands during the early 1630s, Browne developed a highly practical account of both religion and medicine, which in many ways exemplified the progress of a disenchanted religious imaginary, in an age of sectarian extremes. How did such an imaginary differ from the world of the recent past? The tone of Browne's medical training offers us a clue. While medical students of Browne's generation were equipped to pursue their studies within explicitly religious and moral bounds, there was increasing impatience with the classical authorities, which had dominated medicine since the early Middle Ages. In this new atmosphere of inquiry, authority was subservient to observation, just as practical effects trumped Scholastic speculation. In this regard, Browne showed considerable interest in the Ancient Sceptics, whose freedom from dogma gave him an intellectual template for his medical practice. As Browne suggests in his highly confessional work, Religio Medici:

We do but learn, to-day, what our better advanced judgments will unteach to-morrow; and Aristotle doth but instruct us, as Plato did him, that is, to confute himself. I have run through all sorts, yet find no rest in any: though our first studies and junior endeavours may style us Peripateticks, Stoicks, or Academicks, yet I perceive the wisest heads prove, at last, almost all Scepticks, and stand like Janus in the field of knowledge. I have therefore one common and authentick philosophy I learned in the schools, whereby I discourse and satisfy the reason of 
other men; another more reserved, and drawn from experience, whereby I content mine own (Browne 1902, pp. 105-7).

However, as a modern biographer of Browne has pointed out, this deeply empirical thinker frequently expressed a 'lingering dissatisfaction with a curriculum that reduced wisdom to praxis' (Barbour 2013, p. 191). It is here that Browne's overtly Latitudinarian Anglicanism comes into stark focus. While medicine personified the wisdom and ingenuity of human beings, such terrestrial insight always paled in comparison to the wisdom and foresight of God. As Browne summarises this cosmic vision:

[There] are two books from Nature a whence I collect my divinity. Besides written one of God, another of his servant, nature, that universal and publick manuscript,that lies expansed unto the eyes of all. Those that never saw him in the one have discovered him in the other: this was the Scripture and Theology of the heathens; the natural motion of the sun made them more admire him than its supernatural station did the children of Israel. The ordinary effect of nature wrought josh. x. 12, more admiration in them than, in the other, all his miracles. Surely the heathens knew better how to join and read these mystical letters than we Christians, who cast a more careless eye on these common hieroglyphicks, and disdain to suck divinity from the flowers. (Browne 1902, p. 21).

Despite his majestic appeals to grand cosmology, however, Browne was incapable of separating his faith from the sceptical method of inquiry learnt during his medical training. In this spirit, he is honest with his reader that much of the Christian faith (particularly the speculation of theologians) utterly baffles him. He does not know whether the miracles of Scripture have 'ceased' (Browne 1902, p. 41) nrownor is he certain concerning the exact nature of Hell, nor the character of heaven (Browne 1902, pp. 72-73). While he insists that there 'is surely a piece of divinity in us' (Browne 1902, p. 122) and that 'our ashes shall enjoy the fruit of our pious endeavours' (Browne 1902, p. 73), his medical training had taught him that the body functioned according to explicable natural laws, with no obvious place for a soul. In this vein, apart from his Saviour, Browne utterly dismisses those who claim to have resurrected the dead (Preston 2008, p. 221). Here, we see the secularisation of the body in outline. For Browne, the physical life may be restored in a future eon by God's grace (as the Creeds imparted), but in this life, the body was not a vessel of divine power. By loosening his faith in the externality of the enchanted world, Browne inevitably turns progressively inward, finding spiritual symbols in his own psyche, rather than out in the world: "The heart of man is the place the devils dwell in; I feel sometimes a hell within myself; Lucifer "keeps" his court in my breast; Legion is revived in me' (Browne 1902, p. 77). Because of these doubts, Browne could not bring himself to uncritically endorse any of the numerous sects offered by the spiritual market-place of 17th century England. Such a refusal led Browne into an apparent contradiction; a firm commitment to the Anglican faith, combined with a studious respect for other confessions. While Browne was not an advocate of high church pageantry nor cultic enthusiasm, he could not agree with the Puritans that such practices should be rejected: 'I cannot laugh at, but rather pity the fruitless journeys of pilgrims, or contemn the miserable condition of friars; for, though misplaced in circumstance, there is something in it of devotion' (Browne 1902, pp. 3-4). What matters to Browne are not the external trappings of ecclesial belonging, but rather the internal dispositions of the worshipper, and whether, in the end, particular theological beliefs turn out to be useful. In a fascinating passage on common beliefs concerning guardian angels, Browne notes:

I am so far from denying their existence, that I could easily believe, that not only whole countries, but particular persons, have their tutelary and guardian angels. It is not a new opinion of the Church of Rome, but an old one of Pythagoras and Plato: there is no heresy in it: and if not manifestly defined in Scripture, yet is it an opinion of a good and wholesome use in the course and actions of a man's life, and would serve as an hypothesis to salve many doubts whereof common philosophy affordeth no solution. (Browne 1902, p. 48). 
Here, the methodical approach of the physician corrodes the definitive status of cherished theological beliefs. Personal benefits, and not metaphysics, is Browne's chief concern. How does Browne think we ought to reflect and act in such an open-ended world? When confronted with hardened religious sectarians, Browne regarded the meaning and efficacy of church rites as a matter of private conscience, not public scrutiny. In accord with this logic of pragmatic moderation, Browne saw nothing amiss in combining his status as a congregant with a passion for astrology (Geneva 1995, p. 67) and hermeticism (Dunn 1950, p. 82). Just as the physician may adopt multiple treatments until he stumbles upon the right diagnostic tools, Browne conducts his spiritual life as an experiment, confined neither by the strictures of agreed doctrine, nor ceremonial conformity. What shall we make of Browne's deeply pragmatic Christianity? In her 1970 study, Natural Symbols, the anthropologist, Mary Douglas, draws attention to the role of rituals in organising and sustaining social and religious worldviews. As Douglas defines the role of ritual:

The drawing of symbolic lines and boundaries is a way of bringing order into experience. Such non-verbal symbols are capable of creating a structure of meanings in which individuals can relate to each other and realize their own ultimate purposes. Learning and perception itself depends upon classifying and distinguishing. Symbolic boundaries are necessary even for the private organizing of experience. But public rituals that perform this function are also necessary to the organizing of society. (Douglas [1970] 1996, p. 53).

Where the shared meanings generated by social ritual are despised, or otherwise downgraded, the external world is likely to lose its significance as the individual mines subjective experience to compensate for the loss of public symbols. If the world of shared ritual invites bodies and communities into magical relations, which unite their inner and outward worlds, a recession of ritual brings about a highly interiorised society, where individuals can actively choose to selectively re-imagine or otherwise qualify religious symbols. At its most extreme, the post-ritual condition allows the individual to walk away from the community. Although, as Douglas is at pains to stress, the freedom to 'say goodbye and walk away does not necessarily imply a loss of religious belief, but it does shake the walls of established religions. Open society leads to private religion' (Douglas [1970] 1996, p. xix). How does Browne's approach to religion and medicine map onto this account concerning the decline of shared worldviews? While Browne's eclectic religiosity does not represent full disenchantment, he repeatedly gestures at the relegation of an enchanted cosmos to an ever more expansive private sphere, as predicted by Douglas. Anglicanism may be a central part of the symbolic order of Browne's world, but it is not all there is. He is not fully absorbed into the symbolic meanings of his faith. The rituals that are supposed to sustain the coherence of his worldview are qualified by other private interests, which in turn possess their own cosmological demands on his conflicted imagination. In the fog of myriad claims and counter-claims, Browne readily admits to his reader that many aspects of his faith perplex him:

It is impossible that, either in the discourse of man or in the infallible voice of God, to the weakness of our apprehensions there should not appear irregularities, contradictions, and antinomies: myself could show a catalogue of doubts, never yet imagined nor questioned, as I know, which are not resolved at the first hearing; not fantastick queries or objections of air; for I cannot hear of atoms in divinity. I can read the history of the pigeon that was sent out of the ark, and returned no more, yet not question how she found out her mate that was left behind: that Lazarus was raised from the dead, yet not demand where, in the interim, his soul awaited; or raise a law-case, whether his heir might lawfully detain his inheritance bequeathed unto him by his death; and he, though restored to life, have no plea or title unto his former possessions. (Browne 1902, p. 32).

This passage is significant because it reveals the character of the new medicine of which Browne is a part of. If the older medicine was hospitable to a magical worldview of Paracelsus, the new medical 
technology of Browne is the great Ouroboros eating itself up in the pursuit of knowledge. At the end of this process, the physician continues to praise divine providence, but the object of his praise has been rendered a shadowy possibility during the investigation. The spell has been broken. Browne's doubts may not have banished the sacred from the world, but they represent a significant concession to something much less enchanted.

\section{Early Quakerism: A Return to Enchanted Medicine}

In the discussion above, medicine took on the role of an agent of disenchantment. Browne, the physician and sceptic, while not rejecting an explicitly religious worldview, is inclined towards a secularising private religion of conscience, which accords with the dictates of the pragmatic character of his medical practice. How might Browne's distinctive approach to both religion and medicine help us better understand the response of early Quakerism towards these matters? In contrast to the mild Latitudinarianism of Browne, early Quakerism can be justly regarded as a movement, in explicit opposition to the waning of religious certainty in the face of the new sciences. While first-generation Quakers were far removed from the institutional structures of an enchanted Christendom, one can position Quakerism far closer to an older Medieval imaginary than many of their fellow Protestants. Consider for instance, early Quaker responses to doctrines of sacramentalism. Within the formal institutions of Medieval Christendom, the powers of the Spirit were channelled via numerous forms of mediation. To many ordinary people in pre-modern Europe, the Eucharist was one such source of spiritual power, able to cure sickness, ward off bad luck, and curse the sinner (Hill 2015, p. 145). Thus, it was thought that the Eucharist should only be taken sparingly and under the guidance of the proper authorities, such was its power as a vortex of God's edification and judgement (Taylor 2007, p. 73). Instead of dismissing the possibility of such powers, Quakers maintained their efficacy, but democratised their use. The early Quaker starting point for this belief was the New Testament book of Acts, where Jesus is seen empowering his followers to heal, curse, and even raise the dead, through the power of the Holy Spirit. In this text, the Church is not merely a gathering of believers, but a locus of God's living purpose, expressed in bodies restored and lives irrevocably changed. However, if God had offered his gifts freely to all through the Holy Spirit, why now was a single class of priests said to control and exercise them? Early Friends concluded that the Spirit's power could not be monopolised and that the old 'magic' promised by the outward Eucharist could now be experienced and channelled through their own bodies. When early Quakers sat together in worship they saw themselves as being swept up in the immediacy of Divine power. These newly adopted sons and daughters of God were no-longer bound by temporality but participated in the Heavenly court of Revelation 4. As Fox expressed this exaggerated sense of imminence:

Christ took the Bread and Wine and gave it to His Disciples when He was with them, before He was crucified: but now He is risen and ascended and stands at the Door of your hearts and knocks. And if any man will hear His voice and open to Him-with His Grace and Light and Spirit, by joining to it-Christ tells you in Revelation III, that He will come in and sup with you and you with Him. And here Christ sups with you and you in Him, which is the last supper spoken of in the Revelations: and this is the Spiritual and Heavenly Marriage Supper; and here Christ's words are fulfilled, who said that He would come again and doth not leave His followers comfortless. (Fox 1831b, p. 251).

However, we should not mistake such an appeal to 'inwardness' as synonymous with the reduction of Quaker communion to a purely mental experience, as found in Protestant thinkers, like Zwingli (Davis 2008, p. 163). The Christ who eats in the heart of each believer infuses the body of each participant with 'the heavenly flesh' of Christ. While the Eucharist of old promised the ingestion of the Lamb's body and blood, Quaker worship offered a literal synthesis between fleshliness and divine imminence (Hinds 2011, p. 17). While other Protestants interpreted the Eucharist as a series of august symbols, Quakers saw the true Eucharist as the partaking in a transformed identity, one in 
which Christ lived in the body of each person. What we have here is not a secularising religiosity, but a charismatic bio-spirituality, which regarded embodiment as a portal to divine communion. Yet, if what was being offered was spiritual food (Hebr. 5:12), Mauss is clear that: 'It is in the nature of food to be shared out. Not to share it with others is 'to kill its essence', it is to destroy it both for oneself and for others' (Mauss [1954] 2002, p. 73). At this point, it is vital to recall that for Mauss, there is no such thing as a free gift. All that is given must likewise be given away. In accord with this ancient logic, early Quaker polemicists talked about the misuse and destruction of spiritual gifts through the sorcerer, Simon Magus, who attempted to buy divine gifts for his own possession (Fox 1831b, p. 476). There were also the possessive Pharisee of Matthew 23, who 'shut the door of the kingdom of heaven in people's faces', but do not enter it themselves (Matt. 23: 13). Behind such imagery is the extensive Quaker censure of priests as a professional class of moneyed mediators. As Douglas Gwyn summarises this critique:

In professionalising the ministry, Quakers asserted that the Church had created a guild, operating within a framework of their own conditions. Professional preaching could easily become a preaching for a commission, rather than for a spiritual commission, like Isaiah had (Isa. 61: 1f). The hour glass became the perfect symbol to Friends of a ministry that subsists too much by the world's reckoning. Anxious about the world's time, anxious for the world's security, rather than first seeking the Kingdom of God and his righteousness (Matt. 6:31-33), the professional ministry will find itself concerned with its own perpetuation instead of labouring for the Lord (Gwyn 1986, p. 77).

The implication of such a condemnation is clear. For the power of a divine gift to be maintained, it must be given away, so that the grace of God could freely circulate throughout the community. As Fox notes in one of his epistles, this logic of gift was unnegotiable: 'Christ said to his apostles, disciples, and ministers, when he sent them forth to preach the gospel, freely you have received, freely give' (Fox 1831b, p. 476). Instead of priests charging for their services, God's message should be free to all, just as God's love is without material requirements. The true Church is one in which there is no usury, and no altar rail between believers and the power of the Eucharist. In the terms sketched by early Quaker theology, there is no separation between gift and giver, because the Lord's Supper subsists in the bodies of all those who experience the Inward Christ. How did this rediscovery of the divine economy of gift transform the life of early Friends? Its chief affect was the rediscovery of what Quakers regarded as true medicine, an art which could heal both soul and body. The contours of this rediscovery are set out vividly in the conversion narrative preserved in Fox's Journal. As a young man, Fox was afflicted with recurrent attacks of religiously-induced melancholy, which drove him to seek a variety of treatments. As Fox recalls:

I went to another ancient priest at Mansetter in Warwickshire and reasoned with him about the ground of despair and temptations; but he was ignorant of my condition: he bid me take tobacco and sing psalms. Tobacco was a thing I did not love, and psalms I was not in a state to sing; I could not sing ... After this I went to another, one Macham, a priest, in high account. He would needs give me some physic, and I was to have been let blood; but they could not get one drop of blood from me, either in arms or head, though they endeavoured it, my body being, as it were, dried up with sorrows, griefs, and troubles, which were so great upon me, that I could have wished I had never been born, or that I had been born blind, that I might never have seen wickedness nor vanity; and deaf, that I might never have heard vain and wicked words, or the Lord's name blasphemed. (Fox 2007, pp. 4-5).

Fox's troubles ended, however, once he discerned that only Jesus Christ could heal him of his afflictions. Not only did this experience remove Fox's acute sense of anomie, it also revealed to him the divine origin of the medical arts. In a moment of visionary exaltation, Fox tells us: 'The creation was open to me; and it was showed me, how all things had their names given them, according to 
their nature and virtue. I was at a stand in my mind, whether I should practise physic for the good of mankind, seeing the nature and virtues of the creatures were so opened to me by the Lord. But I was immediately taken up in spirit, to see into another or more steadfast state than Adam's in innocency, even into a state in Christ Jesus, that should never fall' (Fox 2007, p. 17). Here, Fox's vision closely resembles the Paracelsian myth of Adam's perfect knowledge of the healing arts before the ignorance engendered by the fall. According to this mystical reading of Genesis, by naming each of the animals (Gen. 2:20), Adam revealed his faultless perception of the essence of each created thing (Agrippa 1913, p. 212). In some Cabbalistic versions of this myth, Adam was styled as the first Magus, who received the art of natural magic directly from God while in Paradise (Guazzo 1998, pp. 3-4). Included in Adam's occult curriculum was the capacity to heal disease through the esoteric knowledge of herbs and stones. While Fox does not seem to have direct acquaintance with these Cabbalistic and alchemical traditions, it has been suggested that his natural theology was strongly shaped by the Lutheran mystic, Jakob Böhme (1575-1624). Like Fox, Böhme believed that once human beings perceived nature through the spiritual sight offered by divine revelation, the world's secrets would become available to the faithful inquirer (Elmer 1989, pp. 26-29). Regardless of the precise sources of Fox's insights, the point remains that he followed in the footsteps of the alchemical authors in their insistence that medicine could be restored to its former Adamic glory through the transformative power of God's grace. After his vision, Fox found himself able to perform the kind of miraculous healing credited to Adam, the occult physician, and Christ's first Apostles, the original heirs of a new creation. The age of miracles had begun anew. The Spirit-led powers early Quakers attributed to themselves included the ability to read souls and detect the misuse of spiritual gifts. This included the detection of witchcraft. As Fox relates:

And as I was sitting in a house full of people, declaring the word of life to them, I looked at a woman and discerned an unclean spirit in her. I was moved of the Lord to speak sharply to her; and told her, she was a witch. Upon hearing this, the woman went out of the room. Now since I was a stranger there, and I knew nothing of the woman outwardly, the people were amazed by my calling her a witch and told me afterwards that I had a made a great discovery because all the country believed she was a witch. The Lord had given me a spirit of discerning, by which I many times saw the states and conditions of people, and I could try their spirits. (Fox 2007, p. 85).

Here, we see Fox in no doubt about the existence of occult power projected through human bodies. Far from affirming a disenchanted world, Fox is firmly invested in a cosmos where magic and spirits are persistent realities that humans can both influence and perceive. Alongside such psychic capabilities, Fox was credited (and credited himself) with the divinely sanctioned ability to heal diverse afflictions, including blindness, scrofula, small-pox, paralysis, and headaches, (Coudert 1992, p. 46). Some early Quakers went even further in their affirmation of spiritual gifts. In this latter mode, the Quaker faith became an overt bio-spirituality, where the restoration of health and the defeat of sickness, was understood as an explicit marker of salvation. In this vein, some early Quaker women testified that they had experienced painless child-birth (Moore 2000, p. 132), while the charismatic preacher, James Naylor, claimed under interrogation that the Spirit of Christ permitted him to remain vigorous without food, and, more controversially, enabled him to bring the dead back to life:

Q. Doth God in an extraordinary manner sustain thee, without any corporal food?

A. Man doth not live by bread alone, but by every word that proceedeth out of the mouth of the Father: the same life is mine that is in the Father; but not in the same measure.

Q. How art thou cloathed?

A. I know not.

Q. Dost thou live without bread? 
A. As long as my heavenly Father will: I have tasted of that bread, of which he that eateth shall never die.

Qu. How long hast thou lived without any corporal sustenance, having perfect health?

A. Some fifteen or fifteen days sustained without any other food except the Word of God.

Q. was Dorcas Erbury dead two days in Exeter? and didst thou raise her?

A. I can do nothing of my self: the Scripture beareth witness to the power in me which is everlasting; it is the same power we read of in the Scripture. The Lord hath made me a signe of his coming: and that honour that belongeth to Christ Jesus, in whom I am revealed, may be given to him, as when on earth at Jerusalem, according to the measure. (Bayly Howell 1816, p. 834).

The implications of our earlier discussion of Browne should be obvious. In the face of the efficacy of the new science, Browne becomes the epitome of a disquieting state of disenchantment. In this scheme, medicine serves as a proxy for the disintegration of a system of shared symbols which accorded the world a providential meaning. Medicine could document the structures of the world, but it could not ascribe a certain set of meanings to it. In contrast, early Quakers regarded medicine as an agent of spiritual power. Much like the systems of Medieval alchemy, that expected to find the realities of heaven echoed in the things of earth, Quakers understood bodies as sites of spiritual transformation. This alchemical parallel is significant since it suggests that despite the Quaker abolition of much of the external superstructure of an enchanted Christendom, Friends still inhabited a symbolic universe, in which bodies could mediate divine activity. In this framework, the healing arts (physic) is understood as a redemptive Gospel science, which had its roots in the harmonious life of pre-fall humanity. Auxiliary to such a re-configuration for early Friends was the recovery of a logic of divine gift, which permeated their understanding of the Christian life.

\section{Nayler and Fox: Mapping an Enchanted Creation}

Any discussion of healing and medicine among early Friends naturally leads us to consider Quaker attitudes to creation. In later generations, Quakers would become increasingly comfortable with a mercantile economy, which fundamentally contradicted the logic of gift outlined above. As Mauss defined the contrast between these two forms of life: '[we] live in societies that draw a strict distinction ... between real rights and personal rights, things, and persons. Such a separation is basic: It constitutes the essential condition for a part of our system of property, transfer, and exchange' (Mauss [1954] 2002, p. 61). Nowhere is such a logic more starkly demonstrated than in the relation between modern economics and the natural world. Our post-Enlightenment ontology treats the external world as useful, not given. While nature's parts can be exchanged, enhanced, even protected, our treatment of nature is always contrasted with the social treatment we extend to 'persons'. Because the domain of nature is regarded as beyond the realm of sociality (the domain of 'things'), the non-human world is considered beyond immediate consideration. Such was the Quaker embrace of these attitudes in the industrial 18th century, that it is difficult to recall that, for a brief period, the Quaker movement was an implacable enemy of this divided vision of the world, and the philosophy of individual gain co-dependent with it. In reaction to the commodification of the world, early Quakerism developed (albeit in embryonic form) a theology of creation, which attempted to contest Capitalistic forms of commerce and accumulation at their root. What then were Quaker objections to this world 'of things'? Additionally, what did they regard as the source of rising mercantilism? While Friends of the 1650 s never offered a comprehensive analysis of industry, markets, or money, a common set of answers can be pieced together from Quaker polemics, surviving from the period. A common thread running through first-generation Quaker literature is a recurrent link between the misuse of created things and a radical forgetting of the world's divine origin. Just as Browne had been thrown into doubt by materialist possibilities in the 1630s, Fox and fellow Quaker leaders sensed a comparable materialist threat in Cromwell's Protectorate. As Fox recalls this atmosphere: 
One morning, as I was sitting by the fire, a great cloud came over me, and a temptation beset me; and I sat still. It was said, "All things come by nature"; and the elements and stars came over me, so that I was in a manner quite clouded with it. But inasmuch as I sat still and said nothing, the people of the house perceived nothing; and as I sat still under it and let it alone, a living hope arose in me, and a true voice, which said, "There is a living God who made all". And immediately the cloud and temptation vanished away, and Life rose over it all, and my heart was glad, and I praised the living God. After some time, I met with some people who had such a notion that there was no God, but that all things came by nature and I had great dispute with them and overturned them, and made some of them confess that there was a Living God. (Fox 2007, p. 15).

However, what happens to those who remain under a cloud of unbelief? In a 1653 tract entitled The Discovery of Wisdom, the charismatic Quaker preacher, James Nayler, characterise such people as a 'ranting crew', who, in the liberty they accorded to 'the flesh', had given themselves over to pride, vanity, and violence (Nayler 2003a, p. 57). By connecting such degenerate activities with the sorry condition of the fallen Adam, Nayler concludes:

The first man is of the earth earthly: minds earthly things, lives in the earth, delights in the earth, lusts after the earth, covets, contends and sues for it; for his treasure is in the earth and his heart is with it; for it is his portion; and his thoughts, words and wisdom are all employed about it, plotting and forecasting how to compass it and fetch it out of the hands of others, to heap up; but is never satisfied, but is a servant to it; it is his life, his joy; and if it be taken from him his comfort is gone: it is his god, and he worships it, and would have all to worship him because of the abundance of it that he has got together ... (Nayler 2003a, pp. 46-47).

Here, Nayler is clear. The base of the new commercial economy was a form of false worship. While Friends contented themselves with the heavenly light of Christ, the merchants were busily making new gods of their riches. Idolatry and not greed alone, explained the manifold injustices of 17th century England for early Friends. However, with all this talk of 'earth' and the 'flesh', we should not be misled into thinking that Nayler is exhorting his readers to accept some gnostic vision of transcendence. What Nayler objects to in this passage is not the world that God has created, but rather a calculating and grasping spirit, which distorts the world through the pursuit of wealth or power. As Naylor expressed this vision in his 1657 pamphlet, The Lamb's War:

The Lamb's quarrel is not against the creation, for then should his weapons be carnal, as the weapons of the worldly spirits are: "For we war not with flesh and blood," nor against the creation of God; that we love; but we fight against the spiritual powers of wickedness, which wars against God in the creation, and captivates the creation into the lust which wars against the soul, and that the creature may be delivered into its liberty prepared for the sons of God. And this is not against love, nor everlasting peace, but that without which can be no true love nor lasting peace. (Nayler 2003b, p. 16).

Thus, for early Friends, their society did not err simply because they had hired priesthoods, or because it refused to believe that God's spiritual gifts were offered to all. People were also in error because (like the rest of humanity) they had forgotten that the world was a gift of God. Such was Naylor's disgust at the treatment of creation, that in 1655, he condemned the parish teachers of Chesterfield for permitting bull-baiting on the basis that it was immoral to torment animals (Capp 2012, p. 210). In a similar vein, Fox condemned horse-racing as a kind of gluttonous feasting on the creatures of God (Fox 1808, p. 269). One can fully appreciate the deeply enchanted nature of these positions, once one considers the contours of their philosophical opposite. While Quaker preachers, like their Medieval precursors, continued to speak of the world as a living and gifted domain, the educated elites of the 17th century were increasingly speaking of the world in roundly Cartesian terms. According to this latter theory, the world was not a providential domain, but a delicate material 
mechanism that was, in essence, inert. Instead of God's creatures waiting 'with eager longing for the revealing of the children of God', groaning in labour pains' (NIV, Rom. 8:19-23), non-human animals were rendered automata, without consciousness, or awareness (Regan [1983] 2004, pp. 4-5). This permitted the followers of Descartes to perform brutal experiments on animals, without any moral compunction (Regan [1983] 2004, p. 5). Much as the new science of political economy was transforming the world into a colossal marketplace, the new philosophy of Descartes provided ready justification for extending this process of commodification to the level of life itself.

In a world of mechanisms, lusts, and violence, how could the logic of gift be recovered? In seeking to liberate creation from the powers of evil, Naylor and other Friends stood firmly against the new contractual theory of property, which held that God's promise of dominion in Genesis meant that the human desire to accumulate was right and natural (even if the holding of such property dispossessed others). In this regard, Nayler considered the public institutions of 17th century England as odious on account of their fundamental duplicity. While cloaking themselves in the mantle of righteous judgement, the country's rulers had exchanged the law of God (the law of gift) for a human law. The latter regulation oppressed the weak and dispossessed, all in the name of order and justice. As Naylor wrote in 1653:

[All] hearts are full of oppression, and all hands are full of violence, their houses are filled with oppression, their streets and markets abound with it, their courts, which should afford remedy against it, are wholly made up of iniquity and injustice, and the law of God is made altogether void, and truth is trodden under foot, and plainness is become odious to the proud, and deceit set on high, and the proud are counted happy, and the rich are exalted above the poor and look to be worshipped as God, which if any refuse a snare is laid, and bonds and imprisonment is appointed for them as not worthy to breathe in the air, and no law, equity, nor justice can be heard for their freedoms, and this is not done by an open enemy, for then it had not been so strange unto thee, but it is done by those who pretend to be against oppression ... (Nayler 2003a, p. 197).

In place of this politics of appropriation and brutal hierarchy, Naylor argued that humanity's authority over the world was derived ultimately from God and not might. In this regard, Nayler's theology closely anticipated the claim of the 17th century political theorist, John Locke, who insisted that: 'God who hath given the World to Men in common, hath also given them reason to make use of it to the best advantage of Life and convenience' (Locke [1960] 2013, p. 286). In this Lockean account, it was divine, and not human law, which guaranteed both the protection of property and the exercise of individual rights in the face of oppression. Yet, unlike Locke, who regarded people as the sole owners of both their bodies and individual labour (Locke [1960] 2013, pp. 287-288), Nayler asserted that both bodies and their labour belonged to Christ and must be moulded according to a Christlike ethic of service. Here, we can observe what Carole Dale Spencer has called early Quakerism's ethic of 'holiness'. In this vein, the goal of the true Christian was to 'live in a spirit of holiness', acting, not in accord with the transient fashions of the world, but the logic of service and self-denial exemplified in the Cross (Spencer 2007, p. 5). Thus, for Nayler, the ideal disciple was the one who heeded Christ's call to renunciation: "If you want to be perfect, go, sell your possessions and give to the poor, and you will have treasure in heaven. Then come, follow me" (Matt, 19: 21). Charging nothing, taking nothing, these true saints lived by the logic of gift alone. For Nayler, these are 'the wanderers and strangers' who had begun to populate the countryside of England during the civil war. Without family or 'earthly possessions' they 'wait on their Father for food who sends them on their own journey' (Nayler 2003a, p. 199). At its most extreme, Nayler believed that making oneself an object of service meant letting go of individual identity altogether. There are moments of mystic fervour in Nayler's ministry in which this Quaker preacher felt himself so enveloped by the reality of Christ that his personality seemingly melted into the nature of Jesus. A stunning instance of this state of personal surrender is provided by the legal testimony of Martha Simonds, an ecstatic disciple of Nayler's, who followed him into Bristol in 1656: 
Q. Whether didst thou kneel before him?

A. What I did, was in obedience to a power above.

Q. Dost thou own him to be the Prince of Peace?

A. He is a perfect man; and he that is a perfect man, is the Prince of Peace.

Q. Hast thou a Husband?

A. I have a Man which thou callest my Husband.

Q. What made thee to leave him, and to follow James Nayler in such a manner?

A. It is our life to praise the Lord, and the Lord my strength (who filleth heaven and earth) is manifest in James Nayler.

Q. Oughtest thou to worship James Nayler, as thou didst upon thy knees?

A. Yea, I ought so to do.

Q. Why oughtest thou so to do?

A. He is the Son of Righteousness; and the new Man within him, is the Everlasting Son of Righteousness and James Nayler will be Jesus, when the new life is born in him.

Q. By what name callest thou him?

A. Lord.

Q. Why dost thou call him Lord?

A. Because he is Prince of Peace, and Lord of Righteousness. (Deacon 2009, pp. 26-27).

While Nayler's own embodied Christology had tragic consequences for him and his close followers, he was not the first Quaker to posit a close identification between the self and the divine. In the early days of the movement, Fox had been accused of blasphemy because of his identification as the 'Son of God' (Hinds 2011, p. 73). Did these early Friends believe they had become Christ? And what did such an identification mean? As Rachel Muers suggests, finding a satisfactory answer to this question is difficult, not least because early Quaker theological language in this area was highly ambiguous. In Nayler's case, the answers he gave to the authorities avoided saying that he was 'the same person as Jesus Christ', but refused 'to put any space between his story and Jesus' story' (Muers 2015, p. 51). Perhaps the key to this enigma of Quaker divine indwelling is to be found in the vision of medicine we surveyed earlier. If true medicine is a Gospel science capable of restoring created bodies to their original state of perfection, then the medicinal paradigm must also extend to the needful creature in the plural. In this way, Nayler's radical appeal to divine imminence reveals not only the destiny of individual bodies, but the final destiny of all created things. Once creaturely recipients accept divine gifts, they become a mirror of the original gift offered, closing the gulf between the saviour and saved. In this mimetic process of the receiver becoming like the giver, life is transformed from a terrain of labour and gain into a space of mutual exchange, where all of nature is potentially infused with the personality of Christ. This represents a significant ontological break with both Browne's new medicine and Locke's political economy. Instead of being merely for 'use', the natural world is treated as a 'spirit', as full of the subjectivity of the God that made it. What do these theological postures amount to? An excellent summary of this natural theology is found in the work of the mid-17th century aristocrat and philosopher, Ann Conway (1631-1679). Shortly before her convincement to Quakerism in the mid-1670s, Conway composed a short tract in refutation of the new mechanical account of nature entitled The Principles of the Most Ancient and Modern Philosophy. Using an inspired blend of Platonism and Cabbala, Conway provided a philosophical underpinning for many of the theological commitments that underwrote early Quaker preaching. Reflecting on the status of bodies and souls, Conway remarks: 
Cartesian philosophy claims that the body is merely dead mass, which not only lacks life and perception of any kind but is also incapable of either for eternity. The great error must be imputed to all those who say that the body and spirit are contrary things and unable to change into one another, thereby deny bodies all life and perception. This is completely contrary to our philosophy. On this account it is so far from being Cartesianism in a new guise that it can be more truly called anti-Cartesianism ... For truly in nature there are many operations that are more than merely mechanical. Nature is not simply an organic body like a clock, which has no vital principle of motion in it; but it is a living body which has life and perception, which are much more exalted than a mere mechanism or mechanical motion. (Conway 1996, pp. 63-64).

In such a cosmology, bodies become the microcosm that constantly voyages towards the possibilities of a restored macrocosm. In this vein, it is not a heresy to declare personal oneness with the body and spirit of Christ, because, just as the spirit can become flesh (Jn. 1: 14), flesh can become spirit (Conway 1996, p. 40). The theology being gestured at here is certainly one of realized eschatology, but, crucially, it is also one of manifest Christosis. Such a world is not only one in which the ill can be healed of their affliction, and the dead can rise, but also one where the earthly elements serve new imperatives, one where 'Christ is all, and is in all' (Col. 3:11). This model of interpreting Quaker spirituality can be said to unite two influential strands of contemporary scholarship. On the one hand, we have Douglas Gwyn and Rosemary Moore's focus on the political and eschatological nature of Quaker claims (Moore 2000, p. 66), while on the other, Spencer has emphasised the Quaker commitment to a process of 'deification', through a commitment to a life of holiness (Spencer 2007, pp. 2-3). By reading Nayler and Conway side by side, we see that both readings of early Quakerism are in fact part of a single complex continuum, in which politics, eschatology, and holiness constitute a single religious perspective. In a world infused with the enchanted presence of Christ, it was impossible to make hard and fast ontological distinctions between public and private, the sacred and the profane, the Biblical past and an eschatologically charged present. As we shall see in our penultimate discussion, this seeming unwillingness of early Friends to make such distinctions possessed radical implications for their understanding of both society and religious belonging.

\section{Living in the Biblical Present: Text, Enchantment, and Gift}

In the discussion so far, we have surveyed early Quaker attitudes to medicine and creation, finding evidence of a highly enchanted movement that invested the body and nature with spiritual value. Far from a secularising force, first-generation Quakerism appears as a radical agent of resistance against the withering away of an explicitly magical cosmos. In the final part of this article, we shall consider how early Quakers attempted to live in such a world. How was it possible to maintain the continual presence of God in those spaces of law, trade, and politics, where the existence of the Spirit appeared to be denied? How could the world of mundane things be brought into the orbit of the reality of God? To answer these questions, we will consider Quaker attitudes to the Bible at close range. It is in the distinctive Quaker treatment of the Bible that we will discover the precise means through which Friends sustained an enchanted vision of daily life, despite evidence to the contrary. While fellow Protestants tended to regard the stunning events of the Scripture as hermetically sealed in the past, early Quakers argued that the cosmos of the Bible continually mingled with the present, in the lives of the faithful at worship, in ecstatic preaching, and in private prayer. Early Quakers felt themselves repeatedly absorbed into the Biblical narrative, daily re-living the struggles and exaltations of the Apostles and the Prophets. In this respect, outwardly, many early Friends could uphold their social obligations to family and community, while being inwardly estranged from the social conditions of the present. At the same time, Biblical imperatives cut many Friends adrift from ordinary society, setting them on course for direct confrontation with ecclesial and civic authorities. As we shall see, this Janus-faced method of Scriptural reflection had significant implications for the character of early Quaker social action. 
Before delving into these public dimensions of Quaker thought, let us first consider the status of the Bible in structuring early Friends' identity. When the earliest Quakers gathered for worship in the early 1650s, the one cultural artefact that bound them together were the Scriptures. This seems strange, given the highly enchanted nature of early Quaker religiosity. The very name 'Quaker' (used first by the movement's ardent opponents) keeps in view the bodily convulsions that often characterised their worship. How could a people without outwards sacraments, or formalised liturgy develop such an intense spirituality through a religion of the Word? Among Protestant Reformers, experiments in a religion of text and proclamation had frequently generated a decidedly introspective worship-experience, rooted, not in the body, but in the mind. The notion of being 'saved through faith' implied the priority of a self-conscious, willed assent to what was spoken from the pulpit. In this account, what is not of the Word (miracles, praise, even the Eucharist) should be regarded as entirely secondary to the task of declaring the Gospel to a listening faithful. However, for early Quakers, worship was anything but an introspective exercise. For Friends, an intense focus on the words of Scripture frequently produced a profound sense of being inducted into a new reality, which was felt as well as heard. As the Quaker preacher, Francis Howgill, reflected on these early gatherings:

The Lord of Heaven and earth we found to be near at hand, and, as we waited upon him in pure silence, our minds out of all things, his heavenly presence appeared in our assemblies, when there was no language, tongue nor speech from any creature. The Kingdom of Heaven did gather us and catch us all, as in a net, and his heavenly power at one time drew many hundreds to land. We came to know a place to stand in and what to wait in; and the Lord appeared daily to us, to our astonishment, amazement and great admiration ... And from that day forward, our hearts were knit unto the Lord and one unto another in true and fervent love, in the covenant of Life with God; and that was a strong obligation or bond upon all our spirits, which united us one unto another. (Howgill 1984, pp. 9-10)

How could a community gathered around Scripture have such intense experiences? As Mary Douglas has wryly suggested, 'Fundamentalists who are not magical in their attitude to the Eucharist become magical in their attitude to the Bible' (Douglas [1970] 1996, p. 21). Similarly, it could be said that although early Quakerism stripped back the ritual basis of religious life to a bare minimum, such a reduction found rich compensation in an approach that treated the Scripture as a living reality that was continually being enacted in the present. Just as the Eucharist took place in the bodies of individual Friends, it was the Quaker conviction that one's inner life could be reorganised so that one's thoughts and actions could mirror Biblical events. Take, for instance, the early Quaker treatment of the Cross. Much like the devotion of Medieval contemplatives, early Friends frequently treated the crucifixion, not merely as a historical event (a past 'redemptive' act), but a living symbol, which expressed a worshipper's conflict with, and eventual freedom from, sin. One did not simply read off the crucifixion, one lived it. As Fox expressed this idea in an epistle of 1653:

The cross is to the carnal part, which is the ground of images, the ground of the seducers, and the ground of the false prophet and antichrist; the cross is to that ground, to the root and life of it. This being minded, which is pure and eternal, it makes a separation from all other lovers, and brings to God, and the ground of evil thoughts comes to be opened, and the cross is that ground; Cross overturns the world in the heart. Which Cross must be taken up by all who follow Jesus Christ... Where the world is standing the Cross is not lived in. But dwelling in the Cross to the world, here the Love of God is shed abroad into the heart, and the Way is opened in the inheritance, which does not fade away. (Fox 1831a, pp. 66-67).

In this account, the suffering of the Cross possessed two interlocking meanings. In its first aspect, the Cross represented the delusions and temptations that weigh down the soul, while in its second aspect, it represented the power of God that leads the captive personality back to the Light of Christ. Alongside this first meaning, the Cross also provided an evocative idiom through which early Quakers 
could describe the cultural structures and social habits that prevented them from making spiritual progress. The social crucifixions of the world were many, from the dispossession of the poor, to the conceit of the rich. In this vein, when Mary Pennington was convinced by Quaker preaching in the 1650s, she saw it as her task to 'take up the cross to the languages, fashions, customs, titles, honours, and esteem in the world' (Pennington 1821, p. 32). When confronted with the disdain of her family, she tells her reader that they 'made this cross very heavy' (Pennington 1821, p. 32). Given the seemingly forensic way in which many early Friends mined Biblical imagery for personal parallels, it may be justly asked whether Friends were indeed 'fundamentalists' in the way Douglas suggests. Had they merely transferred their sense of 'magic' from ecclesial forms to Biblical texts? Here, we must be cautious over the use of an ambiguous term. In one sense, early Quakers were indeed fundamentalists. They believed that their worship together offered a way back to the life of the early Church. However, such fundamentalism was not crudely imitative, nor did the Bible constitute a totemic object in early Quaker thought. Rather, Scripture was treated as a window, which allowed Friends to firmly establish the character of God's Spirit at work in their lives. The function of reading the Scriptures was not to reproduce the spiritual lives of the past, but to 'live in the same spirit' as the prophets and apostles recorded in the Biblical text. One was to 'dwell in' the original power behind the words of the Scripture, not merely hear them from the relative safety of the pew (Gwyn 1986, pp. 123-24). In short, Friends sought a radically experimental Biblical praxis, one in which the ontological chasms between words and spirit, symbol and reality, were bridged. The truth of the Scriptures, once spoken, was to be 'internalised, known in ourselves' (Muers 2015, p. 37).

How then was this living vision of the Scripture to be worked out? In its inward mode, Scripture was 'lived in' at the level of a Friend's dispositions. This first characteristic of Quaker exegesis is forcefully illustrated in the early Quaker practice of spiritual journal writing. This exercise, often undertaken daily, allowed Friends to measure and interrogate their lives against scriptural models and track their spiritual progress. Once again it is Mary Pennington who offers us a rich window into this important aspect of early Quaker spirituality, through her own journal writing. While offering a detailed catalogue of her past sins and religious insights, Pennington also provides us with an excellent summary of the character-forming and disciplinary function of Quaker spiritual writing. In one illuminating passage, Pennington notes:

In his light I do see the temptations and those infirmities; there do I bemoan myself unto him, and feel faith and strength, which give the victory. Though it keeps me low in the sense of my own weakness, yet it quickens me in a lively hope of seeing Satan trodden down under foot by his all-sufficient grace. I feel and know when I have slipped in word, deed, or thought; and also know where my help lieth, who is my advocate and have recourse to him who pardons and heals, and gives me to overcome setting me on my watchtower; and though the enemy suffered me, in order more and more to wean me from any dependence upon the mighty Jehovah, I believe he will never prevail against me. Oh! that I may keep on my watch continually; knowing the Lord only can make war with this dragon. Oh! that I may, by discovering my own weakness, ever be tender to the tempted; watching and praying lest I also be tempted. (Pennington 1821, pp. 34-35).

Here, the mind and heart contend directly with what oppresses the spirit. Mundane guilts and passions are transformed from wayward sensations into powerful opportunities for detecting the presence of divine guidance. Through this practice of intense self-examination, personal experience is invested with new depths of enchantment through the act of an errant will steadfastly focusing itself on the continuing presence of God. In this process, the Bible provides not only the vocabulary for this experience, but offers a clear teleology to this path of moral transformation. Just as the 'dragon' is defeated by the powers of God (Revert Rev. 7:14), the Friend who struggles against their inner darkness will be washed clean in the blood of the Lamb (Revert Rev. 7:14). Unlike many other confessions that taught that these promises would be fulfilled in a life after death, Friends declared that these blessings were present possibilities, even in the midst of the mundane duties of daily life. However, Friends 
were well-aware that such was the unruly power of Scripture, that to live 'in the spirit' of the apostles and prophets, often meant going out into society, and like them, preach a transformed world, in the name of a transformative God. It was not enough to feel oneself healed by the grace of God, one had to make this sense of inward healing manifest. In this mode, reading the Bible became a means of directly challenging social, economic, and political power. Much as the first Apostles had preached against the dominant authorities of the Jewish and pagan worlds, early Quakers separated themselves from their original congregations, calling to account believers who refused to do likewise (Gwyn 1986, p. 128). In harmony with this mission, Quaker preachers found themselves prophesying in the streets, and 'walking naked' as a sign of God's judgement upon the nation (Su 2007, p. 195). Such prophetic witness also took the form of public confrontation. Spaces that were given over to the denial of God's gifts (both churches and market-places) became sites of religious resistance. Indeed, for Fox, there was little difference between the gift-denying logic of the market, and the hollow preaching of the organised churches (Fox 2007, p. 23). In both cases, human and religious needs had been reduced to a mere transaction to benefit the few. In an effort to overcome such spiritual deadness, early Friends disrupted religious services, preached forthrightly against theological opponents, and, sometimes, accused whole cities of wickedness, as George Fox did in 1651, against the 'bloody city of Litchfield' (Fox 2007, p. 40). All these activities radically reinforced early Friends in their prophetic conviction that they were a holy people whose purpose it was to call their fellow Christians from the fashions and designs of the wider world. Their lives were not bound by the confines of temporal loyalties, but always pointed towards the Kingdom of God. As Isaac Penington expressed the sheer liminality of Quaker identity in this period:

Now our work in the world is to hold forth the virtues of him that hath called us; to live like God; not to own any thing in the world which God doth not own; to forget our country, our kindred, our father's house, and to live like persons of another country, of another kindred, of another family; not to do any thing of ourselves, and which is pleasing to the old nature; but all our words, all our conversation, yea, every thought in us, is to become new. Whatever comes from us, is to come from the new principle of life in us, and to answer that in others; but we must not please the old nature at all in ourselves, nor in any else. And walking faithfully thus with God, we have a reward at present, and a crown in the end, which doth and will countervail all the reproaches and hardships we do or can meet with in the world. (Penington 1995, pp. 93-94).

How did this sense of profound separateness cohere with the language of gift we encountered earlier? Mauss, in his survey of archaic societies, assumes that the transfer of gifts requires a cultic/ritual infrastructure, so that peace is symbolically maintained between humans and the divine. As Mauss reflects on these symmetries: 'The law of friendship and contracts, with the gods, came to ensure 'peace' within 'markets' and towns. This occurred when groups paid visits to one another at tribal festivals and at ceremonies where clans confronted one another and families allied themselves or began 'initiations' with one another' (Mauss [1954] 2002, p. 104). As Christians living without feasts or outward liturgy, early Quakers had no comparable festival structure with which to organise the transfer of gifts within their communities. Moreover, early Friends dispensed with most outward markers that might be used to establish harmony between divine and human worlds. Yet, we should not assume that this rendered early Quaker communities gnostic, or somehow unconcerned with their social surroundings. Here, the logic of Scripture both grounded Friends in the needs of the world, while at the same time, replaced the ceremonial regulation of gift-giving with inwardly directed Biblical symbols. This new working out of the gift economy was made manifest through practices of solidarity, which drew imaginatively upon Biblical models of alms-giving and evangelism. These were not wholly the invention of first-generation Friends, but closely resembled ancient Christian patterns of mutual support. As Peter Brown has recently observed, Christians of the late Roman world were shaped in their attitudes to giving through the rich discourse of wealth and poverty offered by the Hebrew Scriptures. As Brown remarks: 
The absorption of the history and language of the Hebrew Scriptures in the Christian communities between the fourth and sixth centuries slowly but surely added a rougher and more assertive texture to the Christian discourse on poverty. The poor were not simply others-creatures who trembled on the margins of society, asked to be saved by the wealthy. Like the poor of Israel, they were also brothers. They had the right to "cry out" for justice in the face of oppressors along with all other members of the "people of God". (Brown 2012, p. 80).

Like earlier generations of Christians, the Quaker rediscovery of this language of the righteous poor had an electrifying effect on the formation of early Quaker theology. Like 'the poor of Israel', Friends sought to overturn not only their own oppression, but speak out against the oppression of others. Internally, this meant the creation of inter-communal structures to support Friends under persecution or in prison. Traveling ministers were also deployed to build bonds of material and religious solidarity between Quaker meetings. Externally, speaking for 'the poor of Israel' meant being advocates for the destitute and downtrodden in an age of exploitation and sectarian persecution. As James Naylor defined the character of this social mission in 1653:

Woe is me for you, you high ones, how are you fallen from that tenderness I have seen in some of you when you were sufferers with the people of God! but now the sufferings of the saints are made a talk at your feasts to fill your mouths with laughter; and you can eat and drink and rise up to play, and stretch yourselves upon your beds of ease, but the afflictions of your brethren are not laid to heart ... You are seeking to be high, but you shall find one above you who is angry with the proud and will bring down the mighty from their seats that he may relieve the oppressed and let the prisoners go free, and the Lamb shall take the kingdom. (Nayler 2003a, p. 201).

In this prophetic mould of an Isaiah or a Hosea, the actions of graced bodies, rather than the performance of outward rituals, became the basis of gift-exchange among early Quakers. Yet, in rooting their actions firmly in the world, Friends were not making a concession to the encroachment of the emerging secular. Their political acts were never meant to be expressions of the finality of earthly politics. Instead their practices were always prefigurative. Freeing persons from the bonds of poverty or oppression were not ends in themselves, but pointed to the Kingdom of God, where both creation and God were at peace. Such symmetry was not established by festivals or communal rites, but by bodies given in service to one another. Such advocacy was enchanted because it was intimately linked to Quaker theological postures concerning creation and the body. A world where God healed broken bodies and souls was also one where political life would be conducted within the Spirit of Christ. Anything which refused the gifts of a loving and righteous God was to be condemned, not at the Final Judgment, but in the street and in the churches. This profound sense of Scripture, as lived, takes us to the heart of Quaker eschatology. While other confessions did not expect the age of miracles to erupt in their daily lives, Quaker life was animated by the Presence of a risen Christ, perpetually in the midst of his people. Nothing could be less secular and more enchanted.

\section{Concluding Reflections: Recovering an Unruly Quakerism}

But this rough magic I here abjure; and when I have required/Some heavenly music-which even now I do-To work mine end upon their senses that/This airy charm is for, I'll break my staff/Bury it certain fathoms in the earth, And deeper than did ever plummet sound/ I'll drown my book. Shakespeare, The Tempest (5.1.50).

This article ends much as it began, with the theme of turning religious tides. At the beginning of the 20th century, British and American scholars attempted to re-evaluate the religious legacy of George Fox and the early Quakers, using the new tools provided by comparative religion. While their efforts varied at the level of detail, they were often united by a tendency to treat early Quakerism as an 
exceptional form of mystical Christianity, which was always to be contrasted with the relative crudity of the religiosity of its age. In this vein, William James observed in The Varieties of Religious Experience (1902): 'In a day of shams, it [Quakerism] was a religion of veracity, rooted in spiritual inwardness, and a return to something more like the original gospel truth than men had ever known in England' (James [1902] 2008, pp. 10-11). To lavish praise upon praise, James further insisted that the modern tendency of Christian sects to admit greater religious tolerance was merely a reversion to the position to which George Fox and the Quakers so long ago assumed' (James [1902] 2008, p. 11). This beguiling depiction of Quakerism as a higher form of religious life found fertile soil among modernist Quakers of the era, who sought to marshal their past to develop a liberal and universalistic Christianity for the present. In this spirit of revisionism, the Quaker scholar, Rufus M. Jones (1863-1948), tended to regard early Friends as the spiritual precursors of the kind of humane Platonic/Christian mysticism that he himself practised (Versluis 2017, pp. 38-39). Other Quaker liberals, notably Howard Brinton (1884-1973), emphasised the trans-religious character of Quaker life and mysticism. Viewed through this prism, Quakerism was not merely the haphazard product of its Puritan milieu, but a particular exposition of timeless religious truths (Abbott 2007, p. 84). Uniting these verdicts was the assumption that early Quakerism was radically other from the religious forms that preceded it. The Quaker refusal of outward rituals, their deep commitment to spiritual inwardness, and direct revelation, according to this view, made them trailblazers and proto-moderns. The Quaker refusal to join fellow liturgical Christians in their superstitious 'forms' was the existential equivalent of Shakespeare's Prospero drowning his occult books and breaking his sorcerer's staff. In the modern world marked by the arrival of Friends, there was no room for external magic any longer. Christ and his salvation were within. Only a secular and disenchanted world existed without. By the time Weber's Protestant Ethic was translated into English by Talcott Parsons in 1930, such Quaker exceptionalism had become well-established in the academic imagination.

What do such readings of the past tell us about the state and direction of Quaker Studies? Above all, they point to a pronounced and persistent tendency to produce a deeply monochrome depiction of Protestant religiosity. At their heart is an attempt to discern a series of strident contrasts between a spiritual and disciplinary Protestantism versus an ecstatic and bodily Catholicism. However, such binaries drastically flatten an otherwise complex religious landscape by refusing to admit the hybridity of bodily spirituality, or the possibility of an 'enchanted' Protestantism. This article, in its excavation of an unruly and supernaturally 'charged' Quakerism, has sought to shatter such dualisms at their core. In their deep commitment to a cosmos of spirits, witchcraft, and miraculous healing, one should understand the early Quaker movement not as the unwitting vanguard of a new secularity, but the visceral remnant of a much older worldview, the assumptions of which were widely shared within Medieval Christendom. Instead of counterposing Protestant asceticism with Catholic 'magic', we need to develop a much more sophisticated account of the ways in which Protestant iconoclasm, in the areas of symbol, ritual, and inwardness, often produced new forms of enchantment, which in turn competed with other manifestations of Protestant cosmology. The theological implications of Calvin or Luther were not stable propositions, but could be read in any number of ways. Cartesian dualism was doubtless a vivid symptom of a world in which 'soul' and 'spirit' were increasingly separated from bodies and objects, but this same inwardness could easily bring about a renewal of enchanted experiences. One thinks of a religious personality, like Pascal, who despite being weighed down by the emptiness of a Cartesian universe, could still praise the God of Abraham, Isaac, and Jacob. A world without the old external certainties of Church and Eucharist could produce a kind of spiritual ubiquity, in which the 'charged' quality of enchanted things could become defused through bodies, spaces, and events. In many respects, such ubiquity could leave the world more enchanted than it was before. This, in essence, is what early Quakers discovered in their worship together. Gone were cultic restrictions on those who could wield spiritual power, transforming a hierarchy of responsibility into a democracy of gifts. As we have seen in the early Quaker case, the retreat of older beliefs in society need not permanently injure the fortunes of the old cosmology. Those living in a time of 
transition may redouble their efforts to re-immerse themselves in an enchanted past. It is through this language of re-emersion that we will find the key to the true character of early Quakerism. For some, an appreciation of this fact may endanger their mythic sense of Quakers as mystical radicals and reduce early Friends to the unenviable status of religious reactionaries. An enchanted Quakerism of living nature, witchcraft, and faith-healing may seem less esteemed than the universalism offered by the Enlightened liberal revisionism of a Brinton or Jones. Nonetheless, the restoration of contingency, earthiness, and sheer religious strangeness to the Quaker story may yet provide a richer understanding of early Friends, one that may yet challenge us to think differently about the religious life in our deeply disenchanted present.

Funding: This research received no external funding.

Conflicts of Interest: The author declares no conflict of interest.

\section{References}

Abbott, Post Margery. 2007. Mental Illness, Ignorance or Sin? Perceptions of Liberal Friends. In Good and Evil: Quaker Perspectives. Edited by Jackie Leach Scully and Pink Dandelion. London: Routledge.

Agrippa, Henry Cornelius. 1913. The Philosophy of Natural Magic. Edited by Lauron William Laurence. Chicago: The de Laurence Company.

Barbour, Reid. 2013. Sir Thomas Browne: A Life. Oxford: Oxford University Press.

Bayly Howell, Thomas. 1816. A Complete Collection of State Trials and Proceedings for High Treason and Other Crimes and Misdemeanours. Peterborough: T.C. Hansard, vol. V.

Brown, Peter. 2012. Through the Eye of a Needle: Wealth, the Fall of the Roman Empire, and the Making of Christianity in the West, 350-550 AD. Princeton: Princeton University Press.

Browne, Thomas. 1902. Religio Medici. Edited by Lloyd Roberts. Manchester: Sherratt \& Hughes.

Capp, Bernard S. 2012. England's Culture Wars: Puritan Reformation and Its Enemies in the Interregnum, 1649-1660. Oxford: Oxford University Press.

Conway, Anne. 1996. The Principles of the Most Ancient Philosophy. Translated by Alsison P. Coudert. Cambridge: Cambridge University Press.

Coudert, Alison P. 1992. Henry More, The Kabbalah, and The Quakers. In Philosophy, Science, and Religion in England 1640-1700. Edited by Richard Kroll. Cambridge: Cambridge University Press.

Davis, Thomas J. 2008. This Is My Body: The Presence of Christ in Reformation Though. Grand Rapids: Barker Academic.

Deacon, John. 2009. The Grand Impostor Examined: Or, the Life, Tryal, and Examination of James Nayler, The Seduced and Seducing Quaker with the Manner of His Riding into Bristol. Oxford: Text Creation Partnership. Available online: http:/ / name.umdl.umich.edu/A52692.0001.001 (accessed on 2 November 2018).

Douglas, Mary. 1996. Natural Symbols: Explorations in Cosmology. London: Routledge. First published 1970.

Dunn, William P. 1950. Sir Thomas Browne: A Study in Religious Philosophy. London: Oxford University Press.

Elmer, Peter. 1989. Medicine, Religion, and the Puritan Religion. In The Medical Revolution of the Seventeenth Century. Edited by Roger French and Andrew Wear. Cambridge: Cambridge University Press.

Su, Fang Ng. 2007. Literature and the Politics of Family in Seventeenth-Century England. Cambridge: Cambridge University Press.

Fox, George. 1808. A Journal: Or Historical Account of the Life, Travels, Sufferings of George Fox. Philadelphia: B \& T Kite, vol. 1.

Fox, George. 1831a. A Collection of Many Select and Christian Epistles, Letters and Testimonies of George Fox. Philadelphia: Isaac T. Hopper.

Fox, George. 1831b. Gospel Truth Demonstrated, in a Collection of Doctrinal Books, Given Forth by That Faithful Minister of Jesus Christ, George Fox. New York: Isaac T. Hopper, vol. 2.

Fox, George. 2007. The Journal. Edited by Norman Penney. New York: Cosimo.

Geneva, Ann. 1995. Astrology and the Seventeenth Century Mind: William Lilly and the Language of the Stars. Manchester: Manchester University Press.

Guazzo, Francesco Maria. 1998. Compendium Maleficarum: The Montague Summers Edition. New York: Dover Publications. 
Gwyn, Douglas. 1986. Apocalypse of the Word: The Life and Message of George Fox, (1624-1691). Richmond: United Friends Press.

Hill, Kate. 2015. Baptism, Brotherhood, and Belief in Reformation Germany: Anabaptism and Lutheranism 1525-1585. Oxford: Oxford University.

Hinds, Hillary. 2011. George Fox and Early Quaker Culture. Manchester: Manchester University Press.

Howgill, Francis. 1984. Testimony Concerning Edward Burroughs. In Quaker Spirituality: Selected Writings. Edited by Douglas Van Steere. Mahwah: Paulist Press.

James, William. 2008. The Varieties of Religious Experience. London: Routledge. First published 1902.

Locke, John. 2013. Two Treatise on Government. Cambridge: Cambridge University Press. First published 1960.

Mauss, Marcel. 2002. The Gift: The form and Reason for Exchange in Archaic Societies. London: Routledge. First published 1954.

Mazza, Enrico. 1999. The Celebration of the Eucharist: The Origin of the Rite and the Development of Its Interpretation. Collegeville: Liturgical Press.

Mellor, Philip, and Chris Shilling. 1997. Re-Forming the Body: Religion, Community, and Modernity. London: Sage. Moore, Rosemary. 2000. Light in Their Consciences: The Early Quakers in Britain, 1646-1666. The University Park: Pennsylvanian University Press.

Muers, Rachel. 2015. Testimony: Quakerism and Theological Ethics. London: SCM Press.

Nayler, James. 2003a. Works of James Nayler. Farmington: Quaker Heritage Press, vol. 1.

Nayler, James. 2003b. Works of James Nayler. Farmington: Quaker Heritage Press, vol. 4.

Penington, Isaac. 1995. The Works of Isaac Penington. Farmington: Quaker Heritage Press, vol. 1.

Pennington, Mary. 1821. Some Account of Circumstances in the Life of Mary Pennington. London: Henry \& Darton.

Preston, Claire. 2008. 'An Incomium of Consumption': Letter to a Friend as Medical Narrative. In Sir Thomas Browne: The World Proposed. Edited by Reid Barbour and Claire Preston. Oxford: Oxford University Press.

Regan, Tom. 2004. The Case for Animal Rights. Berkley: University of California Press. First published 1983.

Rodman-Williams, John. 1996. Renewal Theology: Systematic Theology from a Charismatic Perspective. Grand Rapids: Zondervan.

Spencer, Dale Carole. 2007. Holiness: The Soul of Quakerism: An Historical Analysis of the Theology of Holiness in the Quaker Tradition. Bletchley: Paternoster.

Taylor, Charles. 2007. A Secular Age. London: Harvard University Press.

Versluis, Arthur. 2017. Platonic Mysticism: Contemplative Science, Philosophy, Literature, and Art. Albany: State University of New York.

Weber, Max. 2002. The Protestant Ethic and the Spirit of Capitalism and Other Writings. Translated by Peter Baehr, and Gordon G. Wells. London: Penguin. 